\title{
É possível superar a herança da ditadura brasileira (1964-1985) e controlar o desmatamento na Amazônia? Não, enquanto a pecuária bovina prosseguir como principal vetor de desmatamento \\ Is it possible to overcome the legacy of the Brazilian dictatorship (1964-1985) and keep deforestation in the Amazon under control? Not as long as cattle ranching continues as the main cause of deforestation
}

\author{
João Carlos de Souza Meirelles Filho \\ Instituto Peabiru. Belém, Pará, Brasil
}

\begin{abstract}
Resumo: Neste texto, pretende-se ressaltar a relação direta entre o crescente consumo de carne bovina, o desmatamento na Amazônia e a herança da recente ditadura brasileira, responsável pela maior parte dessa devastação. $\mathrm{O}$ artigo demonstra, em resposta à pergunta titular, que o aumento do desmatamento prosseguirá enquanto a pecuária bovina extensiva for o principal vetor de ocupação. Dedica-se, outrossim, a discutir as diferentes razões que justificam a pecuária na região, por que esta atividade sofreu forte expansão nos últimos 50 anos, por que a Amazônia prossegue como fronteira pioneira do país e quão nefasta é a morosidade do ordenamento territorial. Procura, ainda, averiguar as causas da baixa produtividade da pecuária e, por fim, recomenda diretrizes para as políticas públicas, com especial atenção ao ordenamento fundiário, à extensão rural e à política tributária. Argumenta, deveras, que somente uma nova visão do brasileiro sobre a Amazônia poderá garantir o respeito a seus habitantes e a manutenção das florestas tropicais para as próximas gerações.
\end{abstract}

Palavras-chave: Pecuária bovina. Consumo. Desmatamento. Amazônia. Florestas tropicais. Mudanças climáticas.

\begin{abstract}
This article highlights the direct link between fast growing beef consumption, deforestation in the Amazon, and the legacy of the recent Brazilian dictatorship, which is responsible for most of the devastation in this region. In answer to the title's question, the article argues that deforestation will continue as long as extensive cattle ranching remains as the major driving force. It also discusses the different reasons that justify cattle ranching in the Amazon, why such an astounding expansion took place in the last 50 years, why the Amazon is still an open pioneer frontier as well as why land zoning definition is so important. The article evaluates the causes related to the low productivity of cattle ranching in the Amazon and recommends a series of combined public policies, including land zoning, rural assistance and specific tax policies. Finally, the article argues that only a new Brazilian understanding of the Amazon region may lead to respect for its inhabitants and to preservation of its tropical forests for the coming generations.
\end{abstract}

Keywords: Cattle ranching. Consumption. Deforestation. Amazon. Tropical rainforests. Climate change.

MEIRELLES FILHO, João Carlos de Souza. É possível superar a herança da ditadura brasileira (1964-1985) e controlar o desmatamento na Amazônia? Não, enquanto a pecuária bovina prosseguir como principal vetor de desmatamento. Boletim do Museu Paraense Emílio Goeldi. Ciências Humanas, v. 9, n. 1, p. 219-241, jan.-abr. 2014.

Autor para correspondência: João Carlos de Souza Meirelles Filho. Rua Ó de Almeida, 1083 - Reduto. Belém, PA, Brasil. CEP 66053-360 (jmeirelles@peabiru.org.br).

Recebido em 20/03/2013

Aprovado em 10/12/2013

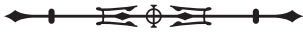




\section{O CONTEXTO}

\section{A HISTÓRIA DO DESMATAMENTO NO BRASIL}

Um dos primeiros quadros a óleo sobre o Brasil, pintado em 1637 por Frans Post, em Pernambuco, como parte do esforço do Príncipe Maurício de Nassau em registrar a região, apresenta uma voçoroca (erosão) - provavelmente causada pelo plantio de cana-de-açúcar - triunfando sobre um local onde fora Mata Atlântica (Figura 1).

Em seus cinco séculos de colonização pelo machado de ferro, o Brasil se transformou em um museu aberto do desmatamento, sua paisagem é o maior museu do desmatamento do mundo. E perpetua-se empurrando o gado para dentro da floresta, o maior legado da recente ditadura brasileira para a história da humanidade. Os brasileiros destruíram cerca de $1 / 3$ de suas florestas tropicais e, o mais impressionante, seguem modificando a paisagem num forte ritmo. As consequências para seus povos nativos não foram menos traumáticas, conforme menciona Daniel Munduruku: "Ailton Krenak afirmou que o Brasil foi construído sobre um cemitério" ( $\mathrm{O}$ índio..., s.d.).

Originalmente, os dois biomas com predominância de florestas tropicais ocupavam, reunidos, 71,55\% do Brasil, ou 6,082 milhões de $\mathrm{km}^{2}$ (608 milhões de hectares), soma da Mata Atlântica (originalmente, com 1,086 milhão de $\mathrm{km}^{2}$ ) e da Floresta Amazônica (originalmente, com 4,196 milhões de $\mathrm{km}^{2}$ ). Quanto a estes e outros números apresentados, certamente os valores podem variar, porém o que ora se persegue é desenvolver uma reflexão sobre o tema. A Mata Atlântica brasileira (havia mais 250 mil km² entre Paraguai e Argentina) perdeu 93\% de sua cobertura - cerca de 984 mil km² (98,4 milhões de hectares) - e foi reduzida a 7\% de sua área - 102 mil km² (10,2 milhões de hectares).

Até 2011, a Amazônia (a brasileira) havia perdido cerca de 748,52 mil km² (74,852 milhões de hectares), 14\% da área florestal (INPE, 2011). Estas perdas totalizam, com a Mata Atlântica, mais de 1,73 milhões de km² (173 milhões de hectares). Mais de 3/4 da área são ocupados pela pecuária bovina extensiva, superfície superior à região Nordeste,

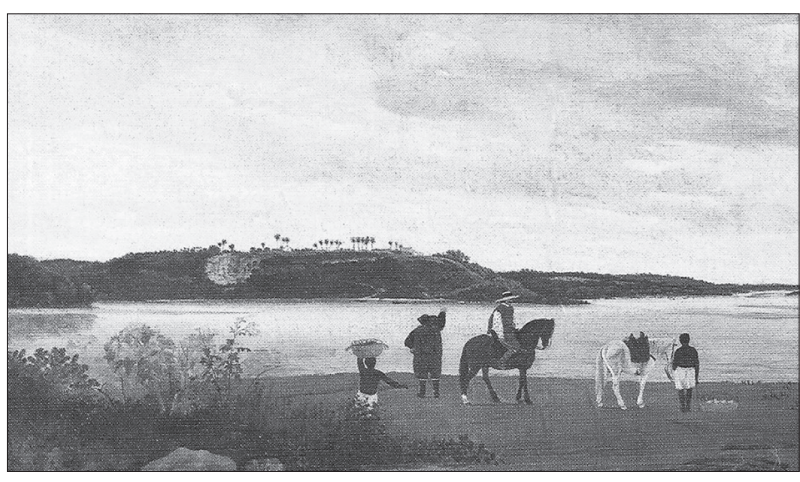

Figura 1. Frans Post (1612-1680), "Gezicht op Itamaracá" (Vista de Itamaracá). Mauritshuis, Den Haag (Haia), Holanda, Inventário N. 915.

equivalente a $20 \%$ do Brasil. A floresta foi reduzida a cerca de 4,344 milhões de km², 71,42\% da superfície original. Se considerada a dimensão temporal, mais de 2/3 dessa perda, superior a um milhão de $\mathrm{km}^{2}$ (100 milhões de hectares), ocorreram nos últimos cinquenta anos, o que alçaria o Brasil a titular da maior destruição de florestas tropicais perpetrada por uma única nação de que se tem registro.

No sentido de avaliar este processo, muitas perguntas provavelmente aflorem, entre as quais estariam: por que destruímos a floresta? E por que no último meio século? Justifica-se esta conversão da floresta tropical em outras atividades? Ao brasileiro e ao planeta, qual o custo socioambiental desta opção? Quem toma as decisões sobre este processo? (Rivero et al., 2009).

Sobre os escombros da Mata Atlântica, vive a maioria dos brasileiros (mais de 150 milhões de pessoas). E, na Amazônia, a população avança, alcançando mais de 12\% do total do país (25 milhões de pessoas). A Mata Atlântica fora ocupada a partir da costa, ao longo de sucessivos ciclos econômicos, contudo, foi a partir do século $X X$ que ocorreu a maior parte do desmatamento. Pode-se até acusar a cana-de-açúcar (e sua demanda por madeira e terras) como algoz da Mata Atlântica nordestina, ou a colonização por imigrantes europeus como a principal causa na sulina, ou o café no Sudeste etc. Todavia, o tiro de misericórdia foi dado pelo ciclo da pecuária bovina extensiva, que, em verdade, prossegue fulgurante. E mais, além de consumir as

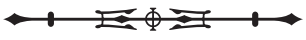


florestas tropicais, ocupa a maior parte dos outros biomas tropicais - o Cerrado e a Caatinga. A Mata Atlântica da Bahia, com 215 mil km² (21,5 milhões de hectares), uma das mais biodiversas do planeta, foi reduzida, especialmente a partir da Segunda Guerra Mundial, a menos de 4\% de sua área. A razão ígnea também é a pecuária extensiva de baixa produtividade, seguida pelo plantio de eucalipto relacionado a grandes conglomerados agroindustriais e, no litoral, pela especulação imobiliária do turismo de sol e praia.

Se, no período pré-colonial, antes da introdução de instrumentos metálicos, a derrubada de um hectare constituíase em evento anual que demandava o esforço coletivo de semanas de um grupo dos mais preparados para a tarefa, a introdução do machado, soberano por cerca de 460 anos, resumiu esta tarefa a dias. Com a motosserra, disseminada a partir do pós-guerra, a horas. A chegada da motorização representada pela motosserra, o buldôzer (trator de esteira) e seus implementos (especialmente o correntão) - ao processo de derrubada da floresta é um divisor de águas. No atual período do Antropoceno, a história deveria ser dividida em dois tempos, Antes da Motosserra (AM) e Depois da Motosserra (DM). Schubart (1977), um dos grandes estudiosos sobre a Amazônia, confere a esta nova era o título de 'era do trator', na qual "desmatamentos de 10 mil hectares num só ano e numa fazenda são comuns" (Meirelles Filho, 2007, p. 144).

Quem percorrer o Espírito Santo e o sul da Bahia terá uma antevisão do museu do desmatamento que pode se tornar a Amazônia. Aliás, seguir pela rodovia Bernardo Sayão (BR-010), mais conhecida como Belém-Brasília, ou pela rodovia Paulo Fontelles (PA-150), que corta o Pará no sentido norte-sul, de Conceição do Araguaia a Moju, nas proximidades de Belém, oferece igual cenário - desmatamento irrestrito, pastagens cercadas e de baixa produtividade, com o 'paliteiro' de grandes árvores mortas, ausência da floresta original, intercalando-se bolsões de exclusão social e grandes propriedades (Figura 2).

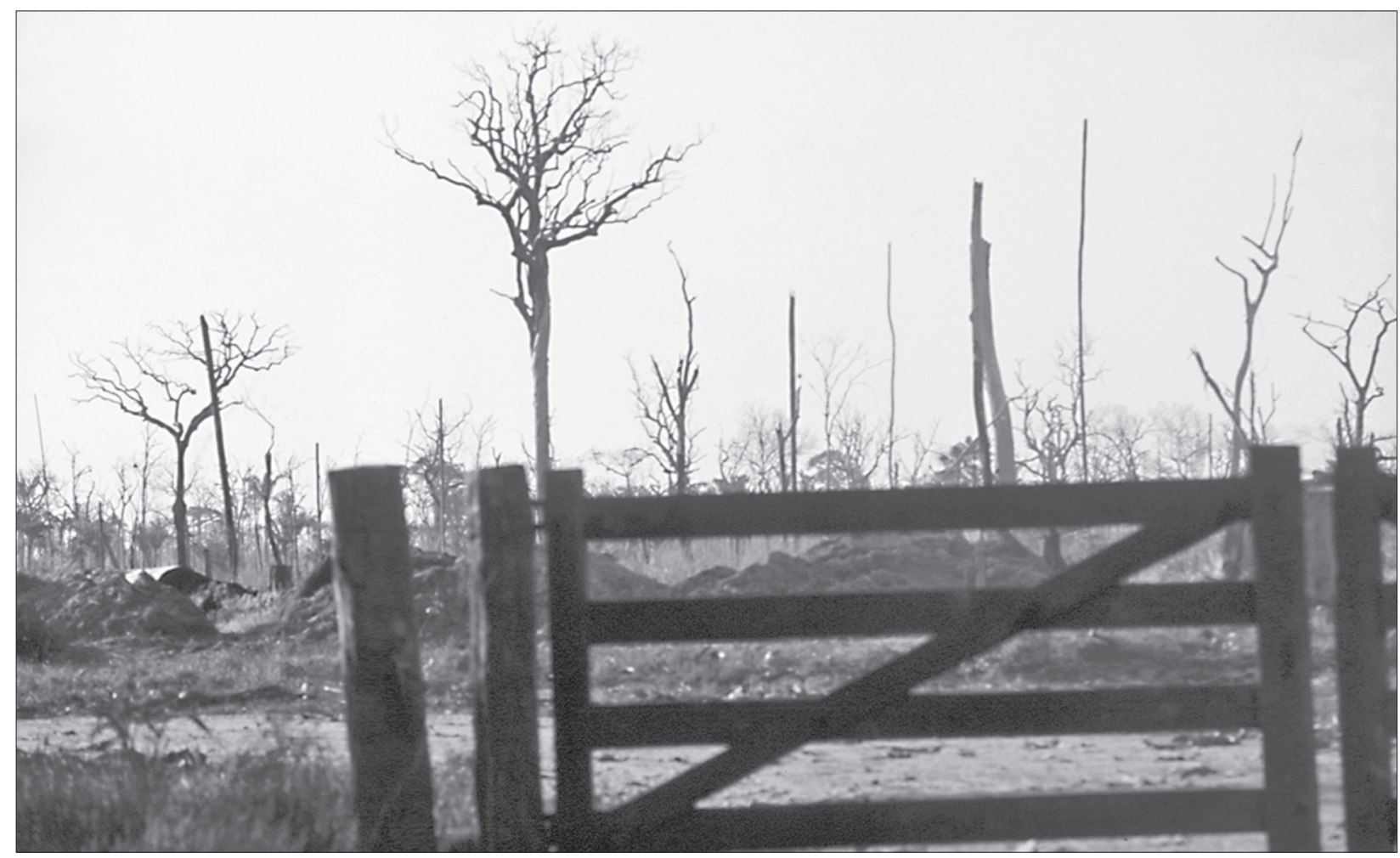

Figura 2. Entrada da Fazenda São Nicolau, que pertenceu ao Grupo Carrefour, em Cotriguaçu, Mato Grosso, 1985. Foto: João Meirelles Filho.

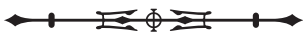


Estima-se que, há dois mil anos, 12\% da superfície terrestre fora coberta por florestas tropicais, cerca de 16 milhões de $\mathrm{km}^{2}$, ou 1,6 bilhões de hectares (Myers, 1986). Hoje, elas se circunscrevem a cerca de 10 milhões de $\mathrm{km}^{2}$ (1 bilhão de hectares). A perda foi de 37,5\% da área original. É como se toda a floresta amazônica continental desaparecesse! Dois terços das florestas remanescentes estariam nas Américas, cabendo ao Brasil cerca de 1/3. Os saldos da Ásia, Oceania e África, divididos em dezenas de países, resumir-se-iam a outro 1/3. Se consideradas as perdas totais de florestas tropicais desde a Segunda Guerra Mundial, o Brasil também seria o campeão e, em termos de desmatamento anual, o país deveras estaria no pódio como líder.

Se dividirmos o número de hectares desmatados de florestas tropicais no Brasil (cerca de 173,8 milhões) pela população brasileira (190,7 milhões), alcança-se a cifra de 0,9113 ha/habitante (IBGE, 2011a). Pesariam, destarte, nas costas de cada brasileiro, $9.113 \mathrm{~m}^{2}$ (quase um hectare) de desmatamento. Se dividirmos a floresta tropical remanescente (cerca de 434,4 milhões de ha) pelo número de brasileiros, alcança-se a cifra de 2,277 hectares/capita. Assim, cada brasileiro recebe de herança cerca de 3,1892 hectares de florestas tropicais, nos quais $7 / 10$ (exatamente $71,39 \%$ ) são ocupados por florestas e $3 / 10$ (exatamente 28,61\%), por terras desmatadas. Esta equação, como se sabe, poderá se alterar.

\section{O DESMATAMENTO NA AMAZÔNIA}

Desde a ditadura civil-militar na década de 1960, e até os dias atuais, o poder público incentiva e subsidia a expansão econômica sobre o bioma amazônico, especialmente da pecuária bovina, com baixíssimo questionamento e resistência da opinião pública brasileira. $\bigcirc$ desmatamento prossegue como sinonímia de progresso. Mesmo a abertura democrática, as novas leis ambientais, a maior capacidade de fiscalização, o monitoramento de satélite, a atuação da sociedade civil organizada, o Ministério Público e o surgimento de novos meios de comunicação não foram suficientes para coibir o desmatamento e a invasão de terras públicas, inclusive territórios indígenas, quilombolas e unidades de conservação.

Segundo o Instituto Brasileiro de Geografia e Estatística (IBGE), em menos de cinco décadas, de 1960 a 2010, a área desmatada alcançou 754 mil km² (75,4 milhões de hectares), cerca de 18\% do bioma amazônico (IBGE, 2011a), número que apresenta pequena diferença sobre o do Projeto de Monitoramento da Floresta Amazônica Brasileira por Satélite (PRODES) (INPE, 2011). Acredita-se que o desmatamento anterior a 1960 seria inferior a 50 mil km² (6,6\% do total). Assim, 704 mil km² (70,4 milhões de ha), ou 93,4\%, teriam sido desmatados em 50 anos, uma média de 14,08 mil km²/ano (1,4 milhões de hectares/ano), área equivalente à soma da superfície de três estados - Minas Gerais, Espírito Santo e Rio de Janeiro.

Se dividirmos o número médio de hectares desmatados nestes 50 anos na Amazônia pela população brasileira, alcança-se a cifra de 0,396 ha/capita $\left(3.960 \mathrm{~m}^{2}\right.$, um terreno de $39 \times 100 \mathrm{~m}$ ). Os índices de desmatamento monitorados pelo Instituto Nacional de Pesquisas Espaciais (INPE) e por outros órgãos oficiais vêm caindo. Do pico de cerca de 27,423 mil km² em 2004, atingiram 4,656 mil km² em 2012, o menor índice dos últimos 23 anos. Mesmo assim, a cifra de 2012 corresponde a uma área de $500 \mathrm{~m}$ de cada lado de uma estrada entre São Paulo e Rio de Janeiro.

Nos últimos 20 anos, uma série de modelagens foi desenvolvida por pesquisadores brasileiros e estrangeiros, em instituições oficiais, como Empresa Brasileira de Pesquisa Agropecuária (EMBRAPA), INPE, Instituto Nacional de Pesquisas da Amazônia (INPA), Museu Paraense Emílio Goeldi (MPEG), da sociedade civil, como Conservation International (CI), Instituto de Pesquisa Ambiental da Amazônia (IPAM), Instituto do Homem e Meio Ambiente da Amazônia (IMAZON), The Nature Conservancy (TNC), ou multilaterais, como Banco Mundial, Organização das Nações Unidas para a Alimentação e a Agricultura (FAO), International Tropical Timber Organization (ITTO), procurando compreender os riscos e as fragilidades da Amazônia. Se há divergências 
acerca do ritmo, das premissas e das consequências, as modelagens são unânimes em apontar, de forma sombria, que, a partir de certas condições, a floresta entraria em declínio, com impacto sobre a biodiversidade, a disponibilidade de água e diversos recursos naturais, e com consequências graves a seus habitantes e a outras regiões do continente (como maiores secas ao celeiro agrícola brasileiro no centro-sul).

A mais recente e abrangente visão sobre a região resulta de um esforço de organizações da sociedade civil de diversos países amazônicos - a Rede Amazônica de Informação Socioambiental Georreferenciada (RAISG). Esta considera a Amazônia continental, com 7,8 milhões de km², onde vivem 33 milhões de pessoas e 385 povos indígenas, e com 45\% da superfície protegida. Este estudo apresenta os cinco principais fatores que pressionam as mudanças no uso do solo, resultando em desmatamento: estradas; petróleo e gás; mineração; hidrelétricas; e queimadas. Pondera que, entre 2000 e 2010, a Amazônia continental perdeu 240 mil $\mathrm{km}^{2}$ de florestas (24 milhões de hectares), área equivalente ao estado de São Paulo, ou a toda a floresta amazônica de um país como o Equador. E conclui: "adverte-se que se as ameaças identificadas nos projetos de transporte (estradas e intermodais), petróleo e gás, mineração e focos de calor, se converterem em pressões no futuro próximo, poderá desaparecer até metade da floresta amazônica atual" (RAISG, 2012, p. 60). Lamenta-se que este estudo não avalie, em separado, o impacto da pecuária.

\section{A FRONTEIRA PIONEIRA ABERTA}

De acordo com um estudo do IMAZON e do Instituto Socioambiental (ISA) (Veríssimo et al., 2011), que considera a Amazônia Legal e não o bioma amazônico, 43\% da Amazônia brasileira (219,7 milhões de hectares) são protegidos, seja por unidades de conservação (22,2\%) ou reservas indígenas (21,7\%). Os outros 57\% (291 milhões de hectares) dividem-se em 102 milhões de hectares de propriedade privada (IBGE, 2006) e 189 milhões de hectares de 'terras desprotegidas' ou 'sob pressão'.
O estudo aponta, ainda, que não basta definir o status da área (se terra indígena, território quilombola, unidade de conservação, assentamento agroextrativista ou propriedade privada), pois atividades ilegais continuam a pressionar as áreas protegidas, promovendo o desmatamento e a 'mineração' dos recursos naturais. Há, praticamente, um hectare de terras sob pressão na Amazônia para cada brasileiro, uma área similar à superfície da Colômbia e Venezuela juntas. Sucede que esta indefinição fundiária, reconhecendo terras indígenas, territórios quilombolas e unidades de conservação, torna toda a região amazônica vulnerável.

Nos últimos 50 anos, a ocupação da Amazônia ocorreu, principalmente, no 'arco do desmatamento', denominado pelo governo federal de 'Arco Verde'. De fato, é a maior frente pioneira da história da humanidade, na região de contato entre o Nordeste, o CentroOeste e a Amazônia. Em 43 municípios dos estados do Amazonas (AM), Maranhão (MA), Mato Grosso (MT), Pará (PA), Rondônia (RO) e Roraima (RR) estão mais de 55\% do desmatamento. É para esta região que se dirigem os esforços de ordenamento fundiário no "Mutirão Arco Verde Terra Legal", parte do Programa Terra Legal Amazônia, do Ministério do Desenvolvimento Agrário. Este visa legalizar "300 mil posseiros que ocupam terras federais não destinadas em 463 municípios dos nove estados da Amazônia Legal" (Brasil, 2013). A ação abrange uma área potencial de 67,4 milhões de hectares. Segundo o governo federal, trata-se de uma parceria com estados e municípios, que "abre nova fase do processo de conservação e implantação de modelos de produção sustentável e de prevenção e combate ao desmatamento e à grilagem de terras na Amazônia" (Brasil, 2013).

Segundo pesquisa do IMAZON, em 2010, o programa não alcançou nem 1,4\% de suas metas e as perspectivas não eram melhores para 2011 (Brito e Barreto, 2011). A situação do Programa Terra Legal não difere de esforços anteriores. Com raras exceções, os programas são abandonados ou se tornam tão morosos que sua eventual eficácia é perdida. A própria 
crise por que passa o Instituto Nacional de Colonização e Reforma Agrária (INCRA), associada à divulgação dos altos índices de desmatamento em assentamentos, corrobora este diagnóstico (MPF, 2012). Mesmo com os avanços no geoprocessamento, o cadastramento ambiental rural (CAR), a maior participação do poder público local e a simplificação de procedimentos de reconhecimento de posse (Terra Legal e outros), os avanços ainda são insignificantes (Brandão Jr. e Souza Jr., 2006; Aliança da Terra et al., 2009).

Numa perspectiva jurídica, o descompasso é ainda maior se for considerado que os órgãos públicos estão atrasados na agenda social e não atendem satisfatoriamente os direitos cidadãos (constitucionais) dos povos originais (indígenas), dos quilombolas (presentes na região desde o século XVIII) e das populações tradicionais (provavelmente, antes ou, pelo menos, desde o século XIX), garantindo-lhes a segurança fundiária necessária. A própria noção de 'posseiro' é vaga. Na maioria das vezes, aos povos tradicionais a posse não está no desmatamento extensivo e na queima anual, mas na segurança do acesso a recursos naturais. Tanto para pequenos quanto para grandes ocupantes, a maior dificuldade é a obtenção da segurança fundiária. Situações que se arrastam há 40 anos, resultantes da legislação proveniente da ditadura - como o decreto-lei que transferiu a propriedade de todas as terras até $100 \mathrm{~km}$ de cada lado das rodovias federais existentes e planejadas da Amazônia para a União (Decreto-Lei n. 1.164/71) - estão no cerne desta questão.

A situação se agrava com as sucessivas mudanças de posse e propriedade pela venda, pela morte de ocupantes, pelo parcelamento ou pela agregação de lotes e outras causas. Enquanto isso, o desmatamento segue como 'marco de posse', e a pressão sobre terras e os recursos naturais associados só aumenta. Ainda que diversos fatores contribuam para o desmatamento, como a expansão da soja, as grandes obras de infraestrutura, a mineração, a desafetação de unidades de conservação e o aumento do desmatamento em assentamentos, este artigo aborda a pecuária bovina extensiva, a qual, como veremos, é, de longe, a principal causa.

\section{A PECUÁRIA E SUAS IMPLICAÇÕES}

\section{O IMPACTO MUNDIAL DA PECUÁRIA}

Na década de 2000, pela primeira vez, organismos multilaterais, como a FAO, passaram a tratar do impacto da pecuária bovina e dos demais animais como problema planetário e urgente (FAO, 2006, 2009). Acusa-se o aumento do consumo de carnes como o fulcro das pressões sobre ambientes naturais, especialmente florestas tropicais, e seus recursos associados (especialmente a água). Com o aumento de renda, a urbanização e a aquisição de novos hábitos alimentares, milhões de pessoas mudaram de dieta, substituindo porções representativas de grãos e outros alimentos por carnes e derivados (Osava, 2009).

O relatório "Livestock in the balance" (FAO, 2009) reconhece que a produção pecuária contribui com 18\% das emissões globais de gases relacionados ao efeito estufa (GEE) e com o aumento do desmatamento em alguns países. Para produzir menos de $2 \%$ do Produto Interno Bruto (PIB) global, exigem-se $26 \%$ da superfície terrestre livre de gelo para pastagens. E mais, 33\% das lavouras são destinados à produção de ração animal. Segundo a FAO (2006, p. xxiii), "a pecuária é um dos maiores responsáveis pelos grandes problemas ambientais atuais. São necessárias ações urgentes para mitigar esta situação".

Em função da crescente demanda por alimentos, há pressão para duplicar a pecuária bovina até 2050, de 229 milhões a 463 milhões de toneladas anuais, um crescimento de 5,5 milhões de toneladas/ano. Nada fácil, pois o crescimento de um único ano corresponde a $2 / 3$ de toda a produção brasileira, que é de 8,5 milhões de toneladas, das quais 6,8 milhões seriam ao mercado interno (MAPA, 2012). Em termos do rebanho, isto significa $73 \%$ a mais de cabeças de gado. Pela primeira vez, aceita-se o axioma de que o planeta não disporia de espaço para abrigar tantos animais, ou seja, não haveria 'fronteiras pioneiras' a converter em agropecuária. Três anos antes do referido relatório, a FAO já apresentara documento com perspectivas pessimistas, "A longa sombra da pecuária", no qual alertou que o crescimento

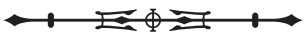


da demanda por carne aumenta a insegurança alimentar entre os grupos excluídos: "Ao mesmo tempo, milhões de pessoas da população rural ainda mantêm produção pecuária pelos sistemas tradicionais, como base de subsistência e garantindo alimentação doméstica" (FAO, 2006, p. 18; ver também Freeman et al., 2007; Goodland e Anhang, 2009).

\section{O CENÁRIO BRASILEIRO}

Nas últimas décadas, o Brasil se tornou detentor do maior rebanho comercial do mundo', com 212,8 milhões de bovinos, além de 1,3 milhões de bubalinos (IBGE, 2011b). Entre 1994 e 2007, o rebanho bovino brasileiro cresceu 34\%, de 158,2 milhões para 212,8 milhões (IBGE, 2011a), crescimento de 3,21 milhões de cabeças/ano. Neste período, o país se tornou o maior exportador mundial de carne bovina (além de frango). Esta expansão sucedeu graças ao exponencial aumento do rebanho na Amazônia e aos ganhos de produtividade (especialmente entre médios e grandes produtores). Ainda que a produtividade média nacional tenha crescido - em 2006, havia cerca de 190 milhões de hectares para 199,7 milhões de cabeças, praticamente uma cabeça por hectare -, esta ainda é extremamente baixa.

Outro fator relevante é a forte interferência do governo federal na cadeia produtiva da carne, na qual investiu mais de $\mathrm{R} \$ 10$ bilhões nos últimos anos, inclusive para ganhar participação no controle do mercado internacional. Tanto fomenta sua oligopolização, participando no capital das principais empresas frigoríficas (JBS/Friboi e Marfrig), buscando a verticalização, como concede créditos subsidiados a grandes pecuaristas por meio de bancos públicos, como o Banco da Amazônia (BASA) e o Banco Nacional de Desenvolvimento Econômico e Social (BNDES).

Quanto ao consumo de carne bovina, no Brasil cresce de maneira firme e consistente, à razão de 0,5 kg/habitante/ ano. Em 2007, cada brasileiro consumia 36,7 kg/habitante/ ano. Hoje, o consumo estaria em quase 40 kg/habitante/ ano. Com milhões de pessoas deixando a faixa da pobreza e ascendendo como consumidores das classes C, D e E, o consumo da carne cresce robustamente. Mesmo porque, no Brasil, comer carne bovina é questão de status social. Nesta perspectiva, em 2030, o consumo deverá alcançar cerca de 50 kg/habitante/ano, próximo daquele dos Estados Unidos (45,3 kg/habitante/ano). Este aumento exigiria um acréscimo de $29 \%$ na produção para o consumo interno, passando de 6,8 milhões de toneladas/ano a 8,8 milhões. Se considerarmos a demanda internacional, especialmente do sudeste asiático (embora na China o consumo de carne bovina alcance meros $4 \mathrm{~kg} /$ habitante/ano, enquanto o de porco chega a 37 $\mathrm{kg})$, um aumento mínimo na procura resultaria em volume considerável. Os analistas do setor afirmam que, dificilmente, haveria carne no mercado para responder a esta demanda.

Estima-se que a pecuária bovina brasileira ocupe 200 milhões de hectares ( 2 milhões de km²), 23\% do país. Nos 27 estados brasileiros e em todos os municípios do país (haveria alguma exceção?), a pecuária está presente. Mesmo nos estados ditos mais desenvolvidos, a pecuária bovina extensiva é, sempre, a atividade econômica que mais superfície exige, inclusive em São Paulo. A maior parte da superfície desmatada de todos os biomas brasileiros é ocupada pela pecuária bovina extensiva (Meirelles Filho e Barney, 2011).

\section{A LÓGICA QUE REGE A PECUÁRIA BRASILEIRA}

Ainda que se convencione denominar de 'ciclos' os períodos da história econômica do Brasil - ciclo do pau-brasil, das especiarias (hoje, se denominariam produtos florestais madeireiros e não madeireiros), da cana-de-açúcar, do cacau etc., há um grande ciclo que se estende indefinidamente - um motto perpetuo -, o ciclo da pecuária. E isto por um conjunto de fatores, dos quais vale destacar oito, a saber (sem uma ordem específica): a) interesse do agronegócio em manter a fronteira aberta, o 'boi-trator'; b) o 'boi-vigia', aquele que guarda a propriedade como reserva de valor, para que o

O maior rebanho do mundo é o da Índia, cerca de 1,5 vezes o brasileiro (incluindo-se búfalos), porém, por questões religiosas, não é considerado um 'rebanho comercial'.

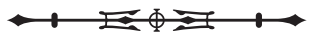


empreendedor não seja acusado de não a explorar; c) o 'boi-poupança', para mais de um milhão de micropecuaristas, a utilização do boi como 'moeda' de poupança; d) não se considera a terra como um capital que precisa ser remunerado; e) a pastagem raramente é considerada como agricultura; f) a maioria não possui planejamento financeiro de seu negócio; g) o 'boi-pirata', que ocupa terras públicas; h) o nível educacional dos pecuaristas, a sua capacidade de acessar e incorporar novas tecnologias e práticas de bom manejo.

Apresentando em maior detalhe os fatores acima sugeridos, no que se refere ao item (a), o 'boi trator' permite que o fazendeiro (de todos os tamanhos), ano após ano, consolide a pastagem. Este processo depende, essencialmente, de sucessivas queimas da área, feito realizado com sagacidade para não implicar responsabilidade por tal ato, algum plantio de capim para complementar as áreas onde este falha e alguma divisão de pasto, para que o gado possa ser melhor manejado. A queima tornará a área 'limpa' e destocada em alguns anos, livrando a propriedade da 'capoeira' (mato, 'juquira', 'inço' ou vegetação sem serventia). Porém, além da área destinada ao pastoreio, afeta-se também a vegetação nativa do entorno. A maior incidência solar sobre a mata restante, o calor dos sucessivos fogos, que muitas vezes penetram nas florestas, a presença do gado, que utiliza estas matas de borda como refúgio e compacta o solo, abrindo caminho para a enxurrada, também alterarão as áreas que deveriam estar cercadas para a proteção ambiental (APP) ou como reserva legal (RL).

Como 'boi-vigia' (b), seu papel é 'guardar' a área (posse ou propriedade). Enquanto isso, a terra, ao longo dos anos, será valorizada (pastagens mais limpas e destocadas; melhor infraestrutura na região etc.). Como atividade de baixo risco e investimento, que exige pouca mão de obra e manejo ínfimo, o gado termina por engordar e, minimamente, promover alguma remuneração ao capital, ainda que sob outra lógica temporal, estendida, pois o objetivo principal é a guarda do terreno e não o giro financeiro.

Quanto ao 'boi poupança' (c), não é uma decisão do produtor, especialmente o micro e pequeno, e sim uma maneira de sobrevivência. Neste caso, deve atingir a maioria dos pequenos produtores na Amazônia. $\bigcirc$ produtor estruturado, com alta produtividade, reclama desta concorrência, pois ele se rege por outra lógica de mercado. No agronegócio, muitos vaticinam que o produtor do 'boi-poupança' desaparecerá, com cerca de 1/3 deles fora do mercado em duas décadas. No entanto, como sua viabilidade relaciona-se a necessidades de subsistência, e não à remuneração do capital, a possível inviabilidade do negócio está longe de ocorrer. $\bigcirc$ 'boi-poupança' fundamenta-se no princípio da reserva de valor, de contar com o recurso para uma necessidade específica - apoiar a educação dos filhos, melhorar a condição da habitação, financiar um evento social marcante (batizado, aniversário, casamento etc.) -, enfim, eventos mais sociais que econômicos. Em alguns casos, o 'boi poupança' peia-se a princípios culturais ultrapassados, como alcançar determinado peso para o abate, não se considerando o tempo que isto demande. Para um pecuarista moderno, perder meses ou semanas no processo de engorda significa menor giro de capital, o que, dificilmente, servirá de métrica ao microprodutor.

O item (d) desconsidera a terra como capital a remunerar. São raríssimos os que medem o retorno do negócio, como deveria fazer qualquer empresário, incluindo o valor da terra, sua depreciação e ativos (demais recursos naturais). Se o fizessem, perceberiam que seu negócio remunera menos que a poupança. $O$ item (e) se refere à maneira como se encara a pastagem. Esta raramente é considerada como agricultura. O pecuarista 'minera' a terra, explorando-a acima de sua capacidade de resiliência. Dela, exuma os minerais (composição química), destrói a estrutura física (resultando em erosão), coleta o que houver de valioso em termos de árvores e, eventualmente, outros vegetais (fibras, castanhas etc.), caça o que alcançar atirar e queima o restante, sem se preocupar com os ciclos naturais básicos da água, dos ventos e biológicos. Se, em regiões temperadas, há noção da necessidade de se replantar as pastagens artificiais, o mesmo não sucede nas regiões tropicais. $\mathrm{Na}$ condição temperada, mais de $2 / 3$ dos nutrientes se encontram no

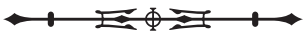


solo. Diferentemente, no trópico, a maior parte está na vegetação e na camada de húmus sobre o solo. A remoção da vegetação e o esvaimento da camada de húmus por meio de sucessivas queimadas (antropogênicas e naturais), as diversas intempéries (alta insolação e temperaturas, ventos, chuvas fortes etc.) e a compactação pelo pisoteio do gado resultam no rápido empobrecimento e endurecimento da maioria dos solos. $\bigcirc$ resultado prático é, num curto prazo de tempo (usualmente, menos que cinco anos), um severo decréscimo na produtividade do pasto. Uma vez empobrecido, o solo será, ainda, objeto de ataque de insetos, especialmente de térmitas e formigas, e a luta entre o capim exótico e a vegetação nativa será incruenta. Raríssimos realizarão o planejamento da propriedade, o manejo adequado, as análises frequentes de solo, água etc., o monitoramento da pluviometria, do balanço hídrico. Da mesma maneira, raríssimos promoverão a adubação, a calagem, a consorciação de leguminosas ou tratos culturais necessários. Igualmente rara é a atenção ao controle da erosão, o respeito à topografia (com a constituição e manutenção de curvas de nível e canais de drenagem) e o manejo para controlar a compactação dos solos, especialmente resultantes dos caminhos que o gado estabelece nas pastagens, que se tornam os leitos por onde a chuva escoa e se voçoroca. Em tempo, é difícil imaginar que um solo que se adaptou à cobertura de um manto florestal tropical, de espesso e variegado dossel com vinte a trinta metros, seja capaz, abruptamente, de oferecer boas condições à monocultura exótica, como o capim, com poucas dezenas de centímetros de altura, ou que se sujeite, frequentemente, à piroagricultura.

Esta desatenção ao patrimônio do solo e do subsolo - arraigada no despreparo do brasileiro em tratar este, que é um de seus maiores patrimônios naturais - resulta em que, dificilmente, se trata a pastagem como agricultura. Raramente 'reforma-se' (replanta-se) a pastagem. A maior parte dos pecuaristas é 'matuta' e, ao invés de investir no restauro do pasto, crê intuitivamente ser mais vantajoso seguir para a fronteira pioneira e desmatar alhures, onde há terras 'frescas', 'virgens', 'descansadas', afinal, há pouca resistência a impedi-lo neste ciclo perverso. Destarte, com a migração e 1/3 da pecuária para a Amazônia, deixam-se para trás 130 milhões de hectares de pastagens em outros biomas, as quais, se reformadas, não justificariam a derrubada de uma árvore sequer da maior floresta tropical do planeta.

Por sua vez, a falta de planejamento (f), questão, de certa maneira, tratada acima, resulta no fato de o pecuarista não ser um empresário, aquele que gerencia um fluxo de caixa projetado, possui e atualiza seu plano de negócios, conhece e apura custos etc. O pecuarista é um artesão, guiado pela intuição, cuja sobrevivência está relacionada à informalidade do setor, à falta de vigilância da sociedade perante os impactos da pecuária, que ocupa um bem escasso, a terra, e não paga seus concidadãos por este desperdício, ou melhor, pela ineficiência. $\bigcirc$ impacto econômico desta 'pecuária de artesão' pode ser visto em todo o país, em municípios com baixa qualidade de serviços e renda ínfima, associada aos bolsões de pobreza, onde grassam a alta concentração de renda, a presença de trabalho infantil, o trabalho análogo à escravidão, o trabalho informal etc. Esta é uma herança que a Amazônia recebeu do Brasil, pois a cultura da pecuária artesanal foi apenas transferida para a região.

O item (g) aborda a delicada questão do 'boipirata', que representa o instrumento para grileiros e invasores usurparem bens públicos, invadindo unidades de conservação, terras indígenas, territórios quilombolas ou terras sem destinação definida, para neles instalarem a pecuária com fins privados. Há diversos registros de ações do Instituto Brasileiro do Meio Ambiente e dos Recursos Naturais Renováveis (IBAMA) e de outras autoridades públicas neste sentido, porém é difícil dimensionar a área impactada.

Por fim, o item ( $h$ ) se refere ao nível educacional dos pecuaristas. Como vimos acima, por ser considerada uma atividade artesanal e intuitiva, formou-se uma crença nacional de que a pecuária não exige mais que conhecimentos rudimentares, que se podem transmitir de maneira simples, sem a presença de um aparato educacional. $\bigcirc$ desinteresse do Estado em regular a atividade e também do consumidor 
em saber de onde veio e em que condições a carne que consome foi produzida, dificultam reconhecer a urgência em profissionalizar a gestão pecuária.

Além destas, poder-se-ia acrescer duas questões: a) a baixa capacidade de trabalho dos órgãos de assistência técnica (extensão rural) e a baixa oferta de capacitação a produtores rurais, o que dificulta ocorrerem mudanças substantivas neste quadro; e b) por falta de alternativas econômicas, a pecuária se impõe como principal forma de subsistência, especialmente a microprodutores rurais, e particularmente em assentamentos. É difícil garantir escoamento, processamento da produção, preços justos e éticos, acesso a crédito, sementes, assistência técnica etc. A maior parte dos assentados é pecuarista por não conseguir exercer outra profissão para sobreviver (Meirelles Filho, 2008, 2009a, 2009b).

\section{NÃO SE PUNE A BAIXA PRODUTIVIDADE}

A produtividade avançou significativamente no Brasil nas últimas décadas. Em uma das diversas análises, Valentim e Andrade (2009, p. 20) afirmam que "a taxa de lotação das pastagens no Brasil aumentou 83\% entre 1975 e 2006, passando de 0,51 para 0,94 unidades animais (UA)/ha". Os autores lembram que, no período inicial estudado, em 1975, havia grande proporção de pastagens nativas e que estas diminuíram significativamente. No entanto, a falta de políticas públicas de longo prazo para o setor e o conservadorismo da maior parte dos produtores resultam na ocupação prioritária de novas terras para, efetivamente, melhorar a produtividade em níveis compatíveis ao que a EMBRAPA e outras organizações de pesquisa admitem como satisfatório. A taxa de desfrute (quantidade de animais abatidos/ano sobre o rebanho) é de cerca de 22\% no Brasil, enquanto nos Estados Unidos ou na Europa é próxima de 30\%. O Centro Brasileiro de Análise e Planejamento (CEBRAP) indica que, com 30\% de desfrute e 1,5 cabeças por hectare, seria possível produzir a mesma quantidade de carne com economia de 69 milhões de hectares (Sparovek et al., 2010). Destarte, se um pecuarista criar mil cabeças de gado em mil hectares ou em cem hectares, dificilmente será penalizado pelo uso excessivo de terra, ou premiado por economizar este fator de produção.

\section{A PECUÁRIA NA AMAZÔNIA E O CENÁRIO DE CRESCIMENTO}

Até a década de 1960, havia menos de 5 milhões de cabeças na região e utilizavam-se, sobretudo, pastagens naturais (várzeas, campos, enclaves de cerrado). No processo amazônico, a grande novidade é a velocidade, tanto do desmatamento como da transferência do rebanho para a região. O Brasil do Sul, Sudeste, Centro-Oeste e Nordeste 'despachou' mais de $40 \%$ de seu rebanho entre 70 a 80 milhões de cabeças - para a Amazônia, em menos de 50 anos, o que equivale a 1,4 milhões de novos animais ao ano. Em determinadas áreas do Sul, por exemplo, houve forte retração no rebanho.

Desde a década de 1960, a área desmatada aumentou 14 vezes e o rebanho, 16 vezes, numa correlação direta entre desmatamento e aumento do rebanho. De 1990 a 2008, o rebanho bovino da Amazônia cresceu de 25,7 milhões a 71,5 milhões de cabeças, um aumento da participação no rebanho brasileiro de 18 a 35\% (Barreto e Silva, 2010). Segundo o Greenpeace (2010), entre 1996 e 2006, as pastagens da Amazônia cresceram em 10 milhões de hectares. Para pesquisadores do Center for International Forestry Research (CIFOR), mais de 91\% da área desmatada é usada para pastagens e agricultada para produzir alimento para os animais (Kaimowitz et al., 2004). Em tempo, todos os estudos apontam para o colossal aumento de pastagens e de bois na Amazônia. Poucos, entretanto, relacionam este crescimento - e o consequente desmatamento - ao forte crescimento do consumo de carne bovina.

Se projetado o crescimento do rebanho bovino para os próximos 20 anos, baseando-se no crescimento de 1,7\% do rebanho do país entre 1994 e 2007, a Amazônia terá 103,7 milhões de cabeças de gado até 2030. Se a projeção for segundo as taxas amazônicas de crescimento, este número seria assaz maior, provavelmente o dobro. 
Este acréscimo, de cerca de 20 milhões de cabeças em duas décadas, exigirá novas pastagens, algo como um milhão de hectares ao ano (10 mil km²/ano). É como se uma área do tamanho do estado do Paraná fosse dedicada aos novos bois da Amazônia em 20 anos. Mesmo com ganhos de produtividade estimados em $20 \%$, a demanda por pastagem ainda será substancial - 16 milhões de hectares, área maior do que o estado do Amapá.

O que se deve temer é a pressão da pecuária sobre a floresta, especialmente sobre os fragmentos florestais nas regiões de maior pressão, como o Arco do Desmatamento. Daí, a urgência de políticas públicas para monitorar a pressão por novas pastagens e seu impacto. Atualmente, a política pública é a 'política de bombeiro': apaga o fogo, mas não sabe por que este se origina; ou a política que combate a febre, mas não a doença. Há poucos indicadores que asseverem que a pecuária bovina buscará maior produtividade (acima de 20\%) para que absorva a demanda por pastagens. Como aludido anteriormente, ainda é mais lógico (ou será mais barato?) prosseguir para a fronteira pioneira e desmatar novas áreas.

A própria classificação do que é 'vegetação secundária' ou 'pastagem degradada' carece de parâmetros mais claros. A proposta de Salomão et al. (2012) aponta caminhos para elucidar esta imprecisão, que dificulta o licenciamento das atividades produtivas e a demarcação das APP e RL. De qualquer maneira, a Tabela 1, elaborada pelo INPE, apresenta a classificação oficial para as áreas desmatadas. Note-se que tão somente as 'pastagens limpas' representam uma área superior à soma das superfícies dos estados de São Paulo, Rio de Janeiro e Espírito Santo. A soma de 'pasto limpo', 'pasto sujo' e 'recuperação de pastagens' engloba 446 mil km² (44,6 milhões de hectares), equivalente aos estados de São Paulo e Paraná. Devese considerar, outrossim, que boa parte da vegetação secundária se refere a pastagens abandonadas e que a pequena propriedade e os assentamentos representam apenas 3,4\% da área desmatada. O Greenpeace (2009) apresenta o caso de Mato Grosso em mais detalhe.
Tabela 1. Classes de áreas desmatadas da Amazônia. Fonte: INPE (2009).

\begin{tabular}{c|c|c}
\hline Classe & Total $\left(\mathrm{km}^{2}\right)$ & Percentual \\
\hline Pasto limpo & $335.714,94$ & $46,7 \%$ \\
\hline Vegetação secundária & $150.815,31$ & $21,0 \%$ \\
\hline Pasto sujo & $62.823,75$ & $8,7 \%$ \\
\hline Regeneração com pastagem & $48.027,37$ & $6,7 \%$ \\
\hline Áreas não observadas & $45.406,27$ & $6,3 \%$ \\
\hline Agricultura (larga escala) & $34.927,24$ & $4,9 \%$ \\
\hline $\begin{array}{c}\text { Pequenas propriedades e } \\
\text { assentamentos }\end{array}$ & $24.416,57$ & $3,4 \%$ \\
\hline Áreas urbanas & $3.818,14$ & $0,5 \%$ \\
\hline Mineração & 730,68 & $0,1 \%$ \\
\hline Áreas degradadas & 594,19 & $0,1 \%$ \\
\hline Outros & 477,88 & $0,1 \%$ \\
\hline Desmatamento em 2008 & $11.458,64$ & $1,6 \%$ \\
\hline Total & $719.210,99$ & \\
\hline
\end{tabular}

\section{ESTIMANDO-SE A ÁREA PARA A PECUÁRIA}

Para se alcançar a área que a expansão prevista da pecuária demandará nos próximos 20 anos, é preciso considerar outros fatores. Segundo a Associação Brasileira da Indústria de Óleos Vegetais (ABIOVE, 2010), entre 2010-2011, havia 1,73 milhões de hectares de soja no bioma Amazônia, entre Mato Grosso, Rondônia e Pará. Neste mesmo período, cerca de 11,65 mil hectares descumpriram a 'moratória da soja' (no ano anterior foram 6,25 mil ha). Esta pressão também deverá crescer nos enclaves de cerrado, como os da Calha Norte e do Amapá, devido ao próprio estímulo dos governos estaduais em desmatar estas áreas. Considerando-se uma média conservadora de 6 mil ha/ano, em 20 anos teremos 120 mil hectares de novos desmatamentos fora da 'moratória' para a soja.

Ao mesmo tempo, espera-se que a soja cresça na substituição de pastagens em pelo menos um milhão de hectares, cifra muito conservadora. Provavelmente, área similar será destinada ao milho, ao algodão e a outras culturas com os novos portos de exportação da região, totalizando mais um milhão de hectares de áreas 
de pastagens. A agricultura perene, como a palma (dendê), o eucalipto e mesmo a proibida cana-de-açúcar, e a fruticultura também deverão alcançar, juntas, pelo menos um milhão de hectares (0,5 milhão da palma e do eucalipto, e cerca de 0,25 milhão da fruticultura e da cana-de-açúcar, respectivamente). Mesmo com a maior fiscalização por parte do poder público, pode-se prever que o desmatamento fique ao redor de $400 \mathrm{mil} \mathrm{ha/ano} \mathrm{(4} \mathrm{mil} \mathrm{km²/ano),} \mathrm{o} \mathrm{que,}$ em 20 anos, significa oito milhões de hectares, dos quais pelo menos 3/4 deverão ser destinados para a pecuária, ou seja, 5,6 milhões de hectares (RSPO, 2006).

Este é um cenário conservador, conforme a demanda para expansão do rebanho de 16 milhões de hectares. A esta devem ser acrescidas: a) pastagens cedidas para a agricultura anual - dois milhões de hectares; b) pastagens transformadas em APP e RL - um milhão de hectares; c) pastagens cedidas para agricultura perene - um milhão de hectares, o que resulta em demanda de 20 milhões de hectares. No lado da oferta, há: a) 11 milhões de hectares entre pastagens sujas e recuperação de pastagens; b) previsão de desmatamento de novas áreas - oito milhões de hectares, totalizando 19 milhões de hectares. Assim, a pecuária bovina ainda necessita de um milhão de hectares, o que certamente 'emprestará' da área de vegetação secundária. Este cenário considera que a vegetação secundária diminuiria pouco, para 14 milhões de hectares, mesmo porque boa parte poderia ser considerada floresta e não apenas vegetação secundária. Neste breve exercício, conclui-se que, a princípio, seriam necessários nove milhões de hectares de novas áreas desmatadas para a pecuária, pouco menor que o estado de Pernambuco.

\section{MUDANÇAS CLIMÁTICAS E A AMAZÔNIA}

A esta perspectiva - do binômio manutenção de razoáveis taxas de desmatamento e expansão da agropecuária na Amazônia -, deve-se agregar a preocupação com as mudanças climáticas globais. Desde que se iniciou a medição das emissões de $\mathrm{CO}_{2}$ e outros gases, a contribuição da Amazônia ao aquecimento global é um tema polêmico. A maior parte dos cientistas acata as estatísticas do
Intergovernmental Panel on Climate Change (IPCC), que, de forma resumida, apontariam para a Amazônia contribuindo de maneira significativa com o aquecimento global em função do desmatamento, das queimadas e do rebanho bovino (metano, principalmente).

Para Fearnside (2006, p. 1), "o desmatamento na Amazônia prossegue em um ritmo acelerado por várias razões, muitas das quais dependem de decisões do governo". O pesquisador entende o desmatamento como uma atividade que provoca perdas de benefícios ambientais que são mais importantes que os benefícios gerados a curto prazo.

Para pesquisadores do IMAZON, "O debate sobre a mudança climática, no entanto, facilitou as políticas e as pressões do mercado contra o desmatamento" (Barreto e Silva, 2009, 2010; Barreto et al., 2008).

A tendência simplificadora e reducionista pode levar a acompanhar apenas a área desmatada anualmente. No entanto, uma área desmatada ainda contém grande quantidade de $\mathrm{CO}_{2}$ acumulada em troncos, galhos, raízes etc., e será queimada por muitos anos. Ninguém sabe, ao certo, qual a área da Amazônia queimada anualmente, nem quanto isto libera de carbono. Os focos de calor são insuficientes para medir esta superfície. Porém, sabe-se que as queimadas seguem como a forma mais utilizada para a 'limpeza' de pastagens. Outra questão é o microdesmatamento, algo que os satélites não identificam. Ele ocorre tanto nas bordas das pastagens como nas áreas de matas ciliares, ao longo de cursos d'água. Somente depois de alguns anos, se compararmos a cobertura florestal de uma área, é possível identificar a área convertida para uso econômico. Nas regiões de mais antiga ocupação e onde a dimensão do lote é menor, esta é a pratica mais comum.

Não se pode afirmar com precisão sobre os impactos das mudanças climáticas no bioma amazônico. que se sabe é que, com um planeta mais quente, a suscetibilidade ao fogo cresce, ameaças à biodiversidade são esperadas, assim como a salinização no espaço costeiro e o aumento de atividades climáticas extremas, 
como tempestades e ventos mais fortes, temperaturas mais altas, maior déficit hídrico nos picos de seca etc. As consequências para a pecuária serão, provavelmente, pastagens menos produtivas e um rebanho mais suscetível à perda de peso. Estes fatores contribuiriam, em um modelo pessimista, para um cenário ainda mais tenebroso, que corroboraria a tese de que 'não é possível estancar o desmatamento'. Isto porque as mudanças climáticas fariam as vezes de fogo antropogênico, motosserras, buldôzeres e agrotóxicos, e poderiam causar danos ainda maiores que a ação humana direta. Como a participação humana nas mudanças climáticas é evidente, elas seriam apenas outra arma humana de destruição, embora indireta.

\section{A AMAZÔNIA NA ECONOMIA GLOBALIZADA}

Se não foi a pecuária que inseriu a Amazônia na economia mundial, nem a exploração ilegal de madeira, pois a maior parte dos consumidores é do Brasil, a globalização da Amazônia cresce especialmente por meio da minerometalurgia, da soja (que alimentará animais em outros países) e de outras atividades conhecidas por serem fortes exportadoras de água. O alumínio, essencialmente, exporta água. A energia elétrica, que representa a maior parte do custo de produção de alumínio, é gerada por hidroeletricidade. As quantidades variam conforme as fontes, mas se considera que um quilo de carne exija mais de 11 mil litros de água, principalmente pelo processo industrial atual. Além das regiões metropolitanas, o presente ciclo de grandes obras é um forte gatilho para o crescimento da pecuária, e é o que sucede no entorno de novas hidrelétricas e das áreas de mineração e metalurgia, como o entorno de Marabá, da serra de Carajás, de Altamira e de Porto Velho, tanto em função do abastecimento de crescente número de consumidores como pela especulação fundiária (Killen, 2007).

Dificilmente, os principais atores dessa questão instituições públicas e companhias privadas - assumirão como sua esta responsabilidade, ou seja, a de coibir o desmatamento no entorno. Da mesma maneira, nos termos de referência dos estudos e relatórios de impacto ambiental (EIA-RIMA), este impacto não é sequer descrito e, muito menos, prevista a sua mitigação, mesmo como contrapartida do poder público. São externalidades raramente consideradas, e mesmo aqueles que as contestam não o formalizam de maneira objetiva, o que possibilitaria o monitoramento dos indicadores de pressão sobre a paisagem natural ou aquela que sofrer interferência parcial. $\bigcirc$ indicador claro, e qualquer leigo pode testemunhar este fato, é que, ao longo das rodovias construídas na maior parte da Amazônia, a pastagem substitui a vegetação nativa.

\section{OUTROS FATORES}

Se, no período inicial dos incentivos fiscais da Superintendência de Desenvolvimento da Amazônia (SUDAM), mais de 590 fazendas de pecuária e agricultura em grande escala receberam incentivo do governo federal, promovendo o desmatamento e facilitando o acesso à invasão de terras e à extração ilegal de madeira, a pecuária extensiva hoje tem acesso a créditos facilitados, com juros baixos (Meirelles Filho, 2007).

Nos últimos anos, com a discussão e definição do Código Florestal e com a maior fiscalização pelo poder público federal (exemplo, a operação 'Arco de Fogo'), a pressão de grupos conservacionistas e do Ministério Público Federal resultou no fechamento de serrarias, em multas a desmatadores, na implementação de embargos a frigoríficos etc. $\bigcirc$ efeito desta campanha foi que o desmatamento 'visível' diminuiu. Grandes cadeias de supermercados, responsáveis por 1/3 da distribuição de carne no Brasil, sentiram-se acuadas com a pressão da opinião pública e assinaram Termos de Ajuste de Conduta (TAC) com o Ministério Público Federal.

Essa recente pressão contra a indústria de carne foi facilitada pelo fato de que o setor está se tornando mais concentrado, portanto mais visível, e mais propenso a se comprometer com melhores práticas ambientais (Cohen e Konar, 2000; Simpson et al., 2007). Contudo, 
a possibilidade de estender e fazer cumprir essa pressão para todo o setor da carne é incerta, pois, em 2006, cerca de 1/3 da atividade de abate no Brasil era clandestina. Em abatedouros clandestinos, não há controle sanitário e fiscal. Este mercado descontrolado e ilegal não obedece a regras e regulamentos e pode continuar comprando de pecuaristas que desmatam (Barreto e Silva, 2010).

No entanto, não houve uma mudança substancial de postura na maior parte dos produtores rurais. Com raras exceções, o microdesmatamento e o uso indiscriminado do fogo prossegue. Este novo cenário não afetou, por exemplo, a lógica do 'boi-poupança', do 'boi-pirata' ou mesmo o crescente mercado de exportação de boi vivo, com mais de 500 mil animais comercializados por ano, em operações que recolhem poucos impostos (Figura 3).

\section{CONSUMO DE CARNE BOVINA - O OSSO DO PROBLEMA}

Diante da fartura de uma churrascaria de rodízio, mesmo os mais conscientes ambientalistas rendem-se à tentação e se enfastiam de carne. $O$ cidadão não relaciona o desmatamento das florestas tropicais - e o impacto a seus povos - com o consumo de carne. Inexistem pesquisas sobre o tema. O principal vetor de destruição da Amazônia - a pata do boi - não comove. Ele sequer reúne pequeno número de pessoas a protestar. Jamais - Brasil considerou o custo da decisão de ocupar o território nacional pela pata do boi ou discutiu, com a profundidade merecida, seu impacto social, ambiental e econômico. Igualmente, não iniciou ampla discussão sobre outras maneiras de produzir proteína animal

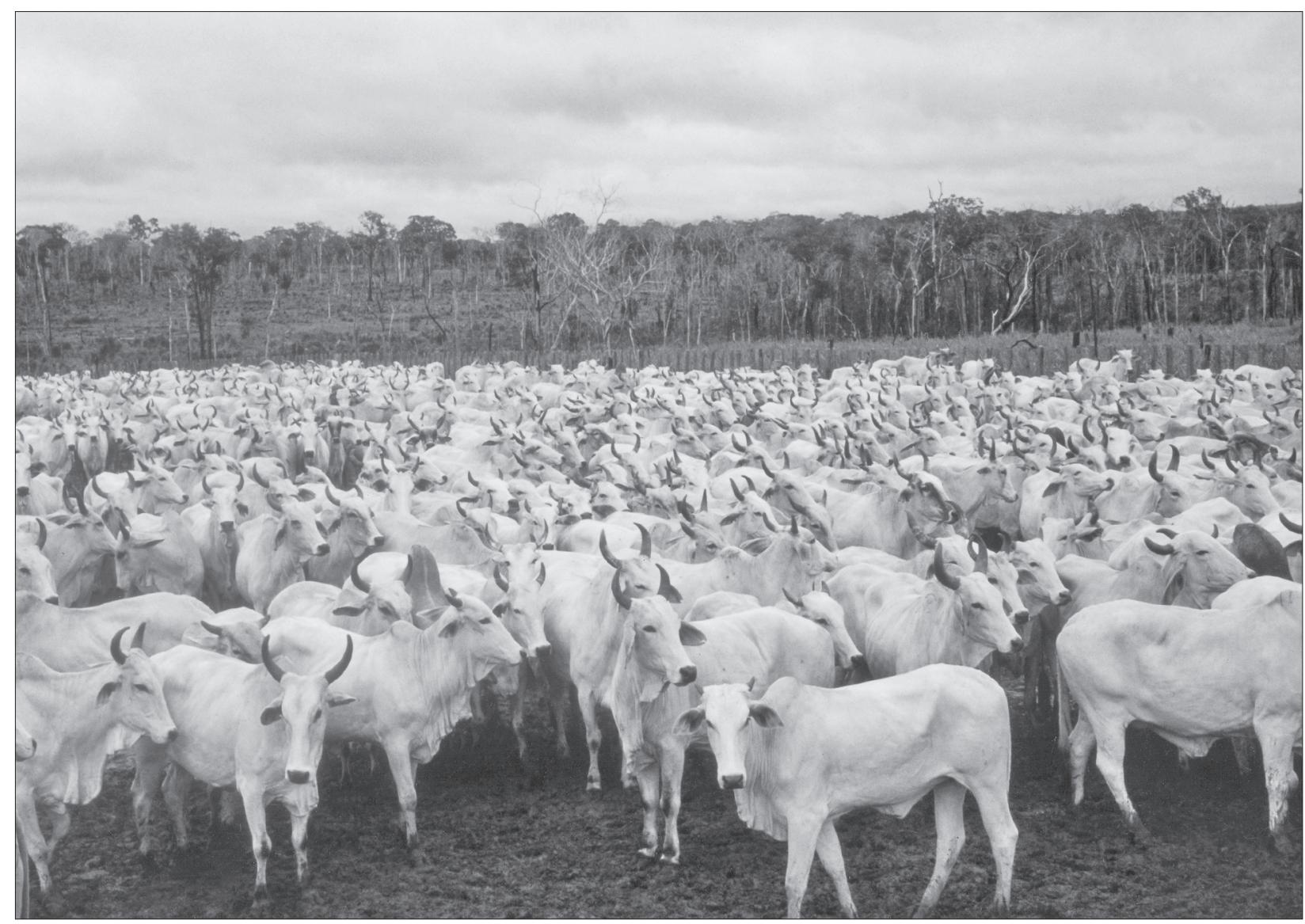

Figura 3. Rebanho de vacas da raça Nelore aguarda para entrar no curral, Mato Grosso, 1986. Foto: João Meirelles Filho.

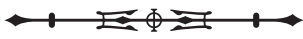


e vegetal em larga escala, de modo a satisfazer as necessidades e os gostos do brasileiro.

Poucos se atentam ao fato de que o boi necessita de muito espaço. No Brasil, utilizam-se 200 milhões de hectares para produzir 8,5 milhões de toneladas de carne bovina, algo como 42,5 kg/habitante/ano. Na prática, dedica-se um hectare para cada comedor de carne no Brasil, levando-se em consideração que o consumo brasileiro, em 2012, era próximo de 39,7 kg/habitante/ano, ou um bife magro de 108 gramas/dia. Sucede que esta cifra (42,5 kg/hab/ano) é risível diante da produtividade da piscicultura (em toneladas), da avicultura ou da criação de pequenos animais.

Se o boi apenas comer pastagens, e esta é a realidade na Amazônia e na maior parte do Brasil, um comedor de carne médio ocupará, durante cerca de 70 anos, um hectare de ambiente tropical devastado (pelo menos 50\% de florestas tropicais) para garantir o seu 'bifinho-de-cada-dia'. Ao final da vida, um consumidor de carne bovina terá comido 20,3 bois ou 2,8 toneladas de carne. Isto é mais do que uma carreta de bois. Destes 20,3 bois, pelo menos sete sairão da Amazônia, numa relação direta do consumidor com o desmatamento. Em 20 anos, mais da metade dos bois do Brasil estarão na Amazônia. Este cálculo lastreia-se no consumo médio de $40 \mathrm{~kg} / \mathrm{ano}$, por 70 anos, e em um boi com peso médio ao abate de 18 arrobas (270 kg), com aproveitamento de carcaça de 51\%, resultando em 137,7 kg de carne/animal.

Qual é o custo, para o país e o planeta, de ocupar área tão grande por tanto tempo e para produzir tão pouco? Este cálculo precisa ser feito em termos financeiros. Além disso, a carne bovina é um 'alimento caro' porque seu preço não incorpora o custo real, a sua 'pegada' de produção. Um quilo de carne bovina precisa de cerca de 11 mil litros de água (alguns falam em até 17 mil) e produz cerca de 15 mil quilos de dióxido de carbono, além de metano. A quantidade de solo desperdiçado, em toneladas, é algo que precisa ser medido e monetarizado.

Acresça-se que o boi, energeticamente, é o animal mais ineficiente que a humanidade poderia escolher. Desde o início dos anos 1970, quando a pesquisadora norte- americana Frances Moore Lappé disse que "para cada 8 quilos de grãos e soja usados para alimentar bovinos de corte nos Estados Unidos temos apenas de volta meio quilo de carne nos nossos pratos" (Lappé, 1971, p. 76), muitos estudos passaram a discutir o custo de produção dos denominados 'alimentos caros'. O boi converte em carne apenas um em cada oito quilos, com eficiência energética de $17 \%$. Comparativamente, as aves convertem cerca de $22 \%$, os peixes, cerca de $30 \%$, e os moluscos, como as ostras, proporções ainda superiores.

Em nível de políticas públicas, sejam globais ou nacionais, pouco se avança na discussão sobre a decisão planetária de obter proteína animal por meio do boi e sobre o esgotamento das terras para sua produção (ou para produzir ração para alimentá-lo). As ditas 'tradições culturais', os dogmas religiosos e a arrogância da maior parte dos países, especialmente os exportadores, impedem que este debate progrida. Esta discussão sequer está presente nos cursos de formação dos profissionais para o setor rural. Poucas são as organizações públicas, da academia ou da sociedade civil, dedicadas à temática. As campanhas e os alertas, até o momento, não produziram qualquer efeito, além de irritar os ditos representantes desta 'tradição' (Figura 4).

Mesmo a discussão do ponto de vista nutricional e da saúde humana, sobre o impacto do consumo de carne bovina, ou as questões apresentadas pelo movimento vegetariano, ainda é algo recente e não interfere nas estatísticas de consumo per capita de carne, por exemplo.

consumidor segue com enorme dificuldade em associar as decisões de consumo, especialmente aquelas relacionadas à comida, com o destino de um bioma, como a Amazônia, ou do planeta Terra. Ao mesmo tempo, o consumidor transfere a responsabilidade por essas decisões ao poder público, e não ao momento em que pilota um carrinho de supermercado. Na próxima refeição, depois deste artigo (indigesto?), poucos se privarão do 'bifinho-nossode-cada-dia' ou do 'churrasquinho-de-fim-de-semana'. No Brasil, de cada três bifinhos, um vem da Amazônia. 


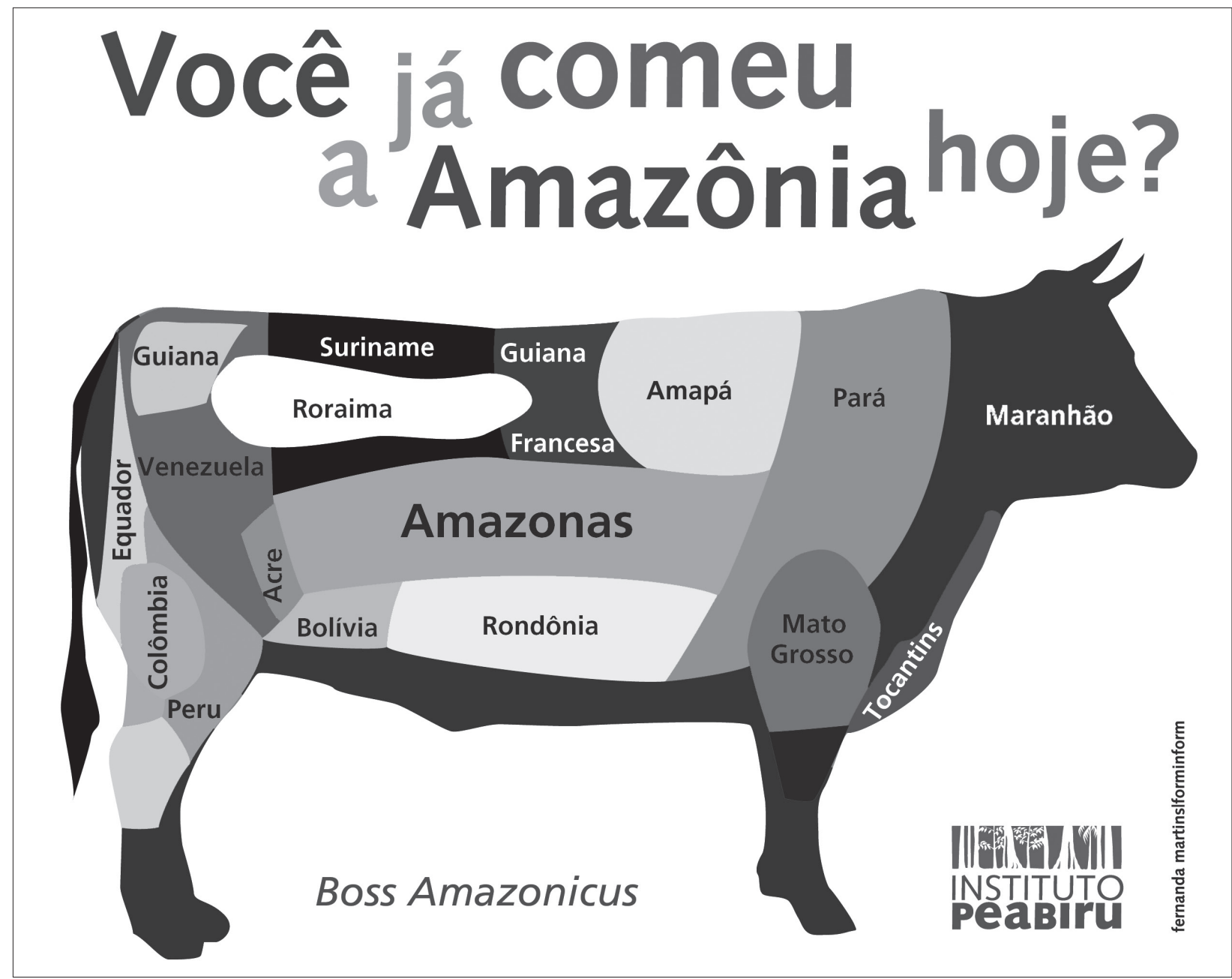

Figura 4. Ilustração da campanha "Você já comeu a Amazônia hoje?", do Instituto Peabiru. Design: Fernanda Martins, Forminform.

\section{CONCLUSÕES E RECOMENDAÇÕES}

\section{PRINCIPAIS CONCLUSÕES}

Brasil está distante de diminuir o desmatamento e o impacto socioeconômico e ambiental sobre as florestas da Amazônia porque o principal vetor de desmatamento não é controlado. Pelo contrário, o aumento do consumo de carne bovina, tanto em nível nacional quanto global, os grandes empreendimentos de infraestrutura e as mudanças climáticas oferecem um cenário sombrio de aumento da pressão sobre as florestas. Ao mesmo tempo, o cerne da questão está na dificuldade do consumidor - e dos gestores públicos que o representam - em relacionar desmatamento e consumo de carne bovina. Na floresta tropical amazônica, esta equação se torna perversa.

Em paralelo, os avanços de produtividade no setor pecuário são insuficientes para afastar a pressão de invasão e desmatamento de terras públicas, e para justificar a recuperação de áreas degradadas, como os 'pastos sujos'. A cultura do desmatamento como sinônimo de 'progresso' e o amadorismo da maioria de produtores rurais ('artesãos rurais') estão entre os principais impedimentos. $\bigcirc$ resultado é que, para cada brasileiro, há um hectare de terras sob pressão na Amazônia. Apesar

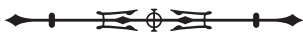


de este ser um tema nacional, não atrai interesse, aliás, nem mesmo entre os amazônidas.

Assim, respondendo à pergunta axial deste artigo, não há como sustar o desmatamento se não houver posicionamento firme das políticas públicas, acompanhadas de forte apoio da sociedade brasileira e regional. Enquanto isso não acontece, a pecuária continuará sendo o principal vetor de pressão sobre a floresta amazônica. E esta vulnerabilidade será tanto maior nas áreas onde o ordenamento fundiário não foi realizado, ou seja, na maior parte da região.

\section{RECOMENDAÇÕES}

Somente um grande esforço nacional conjugado - por meio de políticas públicas, programas do poder executivo, modificação na legislação, campanhas de esclarecimento público (public awareness campaigns), pesquisas científicas e alteração no ensino - poderá resultar em transformações. As propostas a seguir apresentam mui brevemente o que pode ser tratado tanto em nível geral como específico, e não encerram o debate. Visam, em essência, tratar a causa do desmatamento na Amazônia, e não a consequência, como sói ocorrer. Não há uma ordem propriamente dita nas 13 propostas comentadas abaixo, pois elas se entrelaçam.

\section{a) 'Amazonizar' o mundo e assumir a} responsabilidade geracional sobre o desmatamento O senador Cristovam Buarque, em debate realizado nos Estados Unidos, propôs "amazonizar o mundo", recomendando que se adapte o mundo à Amazônia, e não o inverso: "se a Amazônia é uma reserva para todos os seres humanos, ela não pode ser queimada pela vontade de um dono, ou de um país" (Buarque, 2000).

Afinal, são pelo menos 120 séculos de convivência (e lúdico aprendizado) com a floresta tropical, dos quais apenas quatro com a presença europeia e meio de devastação acelerada. $\bigcirc$ sentido que se quer imprimir ao termo 'amazonizar o mundo' é conduzir uma agenda pública, que permita tecer o compromisso, juntamente com as próximas gerações, em prol de uma Amazônia melhor conservada e respeitada do que aquela que o brasileiro hoje conhece. Nesta equação, a moratória ao desmatamento é essencial. O próprio governo federal e o do estado do Pará propõem desmatamento zero. Para tanto, o que se quer promover é a capacidade do brasileiro em assumir sua responsabilidade diante da destruição da Amazônia, assumindo seu papel de cidadão-protagonista para a conservação do bioma e o respeito a seus povos, especialmente os nativos e tradicionais.

A imensa maioria, como se sabe, não se enquizila com o fato de o Brasil destruir a Amazônia. Mário de Andrade já dizia: "o brasileiro vive o Brasil e não o descobre". Esta revisão passa pela própria redefinição de conceitos fundadores, como 'civilização', 'progresso' e 'desenvolvimento'. Até quando 'progresso' será sinônimo de desmatamento, terra arrasada, sem floresta? Até quando o mato será 'feio', 'sujo', 'escuro', lugar do 'selvagem', da 'não cultura', do que precisa ser desfeito e superado?

Em uma perspectiva internacional (há nove países com o bioma Amazônia em seus territórios, mas este artigo trata apenas do Brasil), é preciso se posicionar - afinal, o Brasil e seus vizinhos amazônicos são ou não os guardiões da maior floresta tropical do planeta, e das condições para que seus povos e comunidades tradicionais tenham qualidade de vida e justiça social? Como postula o jornalista Adalberto Marcondes, em depoimento ao autor em 12 de janeiro de 2012, "a Amazônia é o que diferencia o Brasil do resto do planeta". Compartilhando este entendimento com os demais países amazônicos, é preciso perguntar - o brasileiro acredita nisso? Ou o brasileiro ainda acredita que as matas são infinitas, que são muitas as terras disponíveis a explorar, que as águas são abundantes e que a madeira e as riquezas nunca se acabarão?

\section{b) Implementar políticas públicas para o fechamento da fronteira pioneira}

maior desafio, no que tange às políticas públicas brasileiras, é desestimular a abertura de novas fronteiras 
pioneiras. Isto significa encerrar um tempo cultural, uma era de cinco séculos, uma ferida aberta, porém, curável. Para tanto, será preciso superar as incongruências da gestão pública, a qual, de um lado, apoia a conservação, ora timidamente, ora allegro vivace, mas, do outro lado, incentiva a expansão das fronteiras pioneiras, fomentando a pecuária, abrindo dezenas de grandes obras simultaneamente e revertendo parcelas de unidades de conservação em áreas de exploração econômica. A incongruência demonstra que não há um plano estratégico do Brasil para a Amazônia. Se os planos públicos para a região foram, no passado, vagos, pouco seguidos e monitorados, os tempos atuais não permitem mais tal postura.

\section{c) Acelerar o ordenamento fundiário}

Para fechar a fronteira pioneira e enfrentar a maior parte da problemática socioambiental na região, é preciso priorizar o ordenamento fundiário. É preciso imprimir prioridade e vigor para que este processo seja célere e lastreado na justiça social e nas prioridades de longo prazo - de conservação da biossociodiversidade e dos recursos naturais renováveis. É necessário implementar e monitorar os processos de zoneamento ecológico-econômico, nas diversas escalas que ele exige. Como se sabe, o processo atual é bastante moroso e insuficiente.

\section{d) Responsabilizar tecnicamente a gestão de solos, florestas e gado}

Para valorizar o solo, as florestas, a água e os demais recursos naturais, é preciso que haja técnicos responsáveis por este processo - gestores rurais da sustentabilidade. Assim como um engenheiro civil se responsabiliza pela construção de um cômodo de dez metros quadrados, é preciso que haja responsáveis técnicos, capacitados, para assumir a gestão das propriedades e iniciativas rurais, desde as micro às grandes propriedades. O licenciamento destas atividades rurais precisa ser realizado com métrica e transparência, e deve ser renovado regularmente, como se faz em qualquer intervenção urbana. e) Criar um centro para o monitoramento da pecuária Para acompanhar as políticas de zoneamento e o licenciamento, e para monitorar o impacto da pecuária, propõe-se um centro específico, seja em órgão existente ou novo, exclusivo. Além do trabalho realizado pelo INPE e por outros, de monitoramento do desmatamento, é preciso monitorar as causas relacionadas, envolvendo as diversas áreas do conhecimento, com indicadores adequados e na escala suficiente. Esses indicadores devem incluir questões sociais, culturais, ambientais, econômicas, agropecuárias, sanitárias, nutricionais etc. É preciso maior acuidade na medição do impacto da pecuária, para que ela possa responder a perguntas simples - qual o tamanho do rebanho na Amazônia? Qual a área em uso? Qual a produtividade? - e também contribuir com a formulação de políticas temáticas, de legislação e normatização. Este centro muito se beneficiaria se envolvesse a iniciativa privada, a academia e as organizações da sociedade civil.

\section{f) 'Amazonizar' o currículo escolar brasileiro}

Para levar adiante uma proposta transformadora, no sentido de 'amazonizar' o Brasil e o planeta, deve-se revisar o currículo escolar brasileiro. Não se trata de impingir regionalismo obtuso e reducionista, e sim de permitir compreender (e ouvir) a região, seus habitantes e seus anseios. Tanto os brasileiros, em geral, precisam se 'amazonizar', como os próprios amazônidas estão longe de compreender a região em que vivem, tal sua dimensão e complexidade. Este trabalho deve alcançar tanto a formação básica como a técnica e especializada. Especial atenção deveria ser dada à formação de gestores rurais da sustentabilidade, como comentado acima, o que exigiria considerar a biodiversidade, as mudanças climáticas, a sociodiversidade e a justiça social, entre outras temáticas.

\section{g) Estabelecer uma rede de museus do desmatamento}

Relacionado à educação formal e ampliando o espectro ao público geral, propõe-se criar uma rede de museus 
do desmatamento. O objetivo é refletir sobre o desmatamento e seu impacto - cultural, social, ambiental e econômico. Que sejam estes museus os portais para o debate, o registro da memória e da guarda do patrimônio material e imaterial, a produção cultural e a educação patrimonial. A proposta é abranger a educação ambiental como parte de algo maior, que trate da relação do homem com a floresta, da preservação do patrimônio natural às futuras gerações, e não apenas da visão tecnicista. Almeja-se superar a visão imediatista se o desmatamento diminui ou aumenta, e buscar relacionar suas consequências com a visão de civilização brasileira que se pretende. Esta reflexão visa tirar as pessoas do papel de apatia perante a temática, desafiando-as a assumir a responsabilidade coletiva perante o bem comum. Não se trata, necessariamente, de apenas criar novas instituições, pois as existentes poderão ampliar seus horizontes considerando a temática.

Espera-se superar a visão triunfalista sobre a natureza, e avocar compromissos com as populações tradicionais, compromissos intergeracionais, interespécies e planetários. A rede deverá realizar um grande esforço para produzir e compartilhar conhecimento, de maneira que ele esteja amplamente disponível, especialmente em material didático. Caberia a esta rede democratizar o debate sobre as causas do desmatamento, um debate que é, mormente, elitista. A maior parte dos pecuaristas, principalmente os pequenos, ou seja, a imensa maioria, não participa e não associa muitas das questões envolvidas e suas dimensões. Qualificar os representantes e as lideranças locais para o debate é fundamental para este processo democrático.

\section{h) Priorizar a extensão rural a produtores}

Um dos principais entraves para a melhoria da produtividade da pecuária bovina está na baixa capacidade de ação e eficiência dos serviços de assistência técnica rural, em sua maior parte estaduais (Empresas Estaduais de Assistência Técnica), e de órgãos como o INCRA, no que se refere aos projetos de assentamento (via Assistência Técnica Rural).
Muitas instituições não possuem pessoal nem recursos suficientes para enfrentar as demandas do território onde atuam, e a maioria se encontra sucateada, funcionando pelo heroísmo daqueles que realmente se identificam com a missão de assistir os pequenos agropecuaristas.

Deve-se perguntar por que as boas práticas, suficientemente conhecidas pela pesquisa agrícola da EMBRAPA, da academia e das organizações não governamentais, não estão acessíveis às centenas de milhares de agropecuaristas e extrativistas familiares da Amazônia. Da mesma forma, os cursos e as iniciativas do Serviço Nacional de Aprendizagem Rural (SENAR) precisam ser alinhados a estratégias de fortalecimento das capacidades humanas a longo prazo, evitando-se as pequenas complementações técnicas imediatas. É preciso monitorar o desempenho dessas organizações.

\section{i) Implementar a certificação de origem obrigatória}

$\bigcirc$ consumidor brasileiro e o do exterior têm o direito de saber a procedência da carne que consomem (em verdade, de tudo o que consomem). Espera-se que eles se perguntem - qual o impacto de minha decisão de compra sobre o desmatamento na região, sobre a vida das comunidades tradicionais, sobre a biodiversidade e o clima? Se não o fizerem, dificilmente exercerão seu direito de consumidor e sua cidadania brasileira e planetária. Os diferentes elos da cadeia produtiva também devem realizar tal questionamento. Para tanto, o governo federal precisa avaliar o seu posicionamento (Rede de Agricultura Sustentável, 2010).

\section{j) Revisar o regime tributário sobre a pecuária bovina} Se a pecuária bovina é responsável por tão grande impacto àqueles que vivem nas florestas tropicais, ao clima do planeta, sobre os solos e a biodiversidade, e prospera em alta informalidade, uma maneira de controlá-la (e às suas externalidades) é por meio de políticas tributárias. Deve-se pensar na revisão da tributação que incide sobre a cadeia da pecuária bovina na Amazônia, para que o Estado possa arrecadar recursos para se ressarcir pelo uso do patrimônio 
nacional e pelas externalidades que a atividade produz. Além disso, é preciso contar com mecanismos tributários para premiar aqueles que buscam a sustentabilidade e respeitam o uso de recursos naturais e a harmonia com as populações tradicionais. Ademais, o pecuarista é uma das categorias que menos impostos paga no Brasil. Da mesma forma, a propriedade rural pouco paga, e as áreas de baixa utilização precisam ser tributadas, respeitadas, naturalmente, as APP, RL e outras áreas.

\section{k) Fechar o cerco contra a informalidade fiscal}

A informalidade da pecuária bovina na Amazônia contribui significativamente para financiar o desmatamento. Um dos indicadores é o abate clandestino, que, no Brasil, em média, é de 30\% (Amigos da Terra, 2008, 2009, 2013). Na Amazônia, estima-se que ele seja muito maior. Essa evasão fiscal, que prejudica todos os cidadãos brasileiros, revestese ainda da perversidade criminosa, aumentando o risco sanitário ao consumidor de carne, especialmente àqueles que dependem da carne vendida em feiras livres, açougues informais e estabelecimentos irregulares. Muito deste abate se relaciona a abatedouros públicos municipais.

\section{l) Implementar políticas públicas para a valorização da floresta em pé}

Estabelecer um valor à floresta tropical, desenvolvendo maneiras para que seus moradores ou guardiões (públicos ou privados) recebam por isto, seja por meio de serviços ambientais ou pela venda de produtos, é uma das principais frentes de trabalho de diversas organizações em todo o mundo. O pioneiro debt for nature swapp, e mais recentemente o Mecanismo de Desenvolvimento Limpo (MDL), Redução das Emissões por Desmatamento e Degradação florestal (REDD) e REDD +, o bolsa-floresta e iniciativas similares ainda são preliminares para apontar caminhos de larga escala.

Este movimento também pode se associar a políticas tributárias, como o Imposto sobre Circulação de Mercadorias e Serviços (ICMS) verde e outros, com regimes de isenção, subsídios etc. As compras públicas sustentáveis, como a aquisição de produtos da agrobiodiversidade para a merenda escolar e para programas sociais, também se constituem em mecanismo para valorizar a floresta em pé. Em nível público, este tipo de ação ainda é simbólico, e a iniciativa privada pouco se interessa pelas compras sustentáveis.

Por ora, os valores correspondentes a todos os produtos florestais madeireiros e não madeireiros são insuficientes para estimular políticas públicas de impacto, ou mesmo estimular a iniciativa privada a trocar as atividades que se baseiam no desmatamento - onde a pecuária prima por algo que mantenha a floresta em pé. A maior parte das ações ainda opera em escala piloto, insuficiente para alterar o perfil de desmatamento. Isto não deve, contudo, desestimular o processo de desenvolvimento tecnológico nem a implementação de pequenas iniciativas locais.

\section{m) Realizar campanha pública para relacionar consumo e desmatamento}

Essas ações devem ser acompanhadas por ampla campanha de organizações da sociedade civil e de governos nos meios de comunicação, mídias sociais e outros. É preciso municiar o cidadão com amplo cabedal de informações para que possa orientar suas decisões e participar ativamente neste debate.

Por fim, é preciso que o próprio setor pecuarista - seus empresários, executivos, técnicos, pecuaristas familiares atuais e as novas gerações - participe efetivamente deste diálogo e dessas ações. Em uma região caracterizada pela ausência do Estado, é preciso envolver a sociedade civil local e os produtores rurais. Outros setores da sociedade podem até se mobilizar para contribuir, apoiar ou pressionar, mas cabe ao próprio setor rural, em uma revisão de seu papel, ser protagonista, assumindo um novo contrato social com a sociedade. Caso contrário, a Amazônia prosseguirá como o maior museu de desmatamento do planeta. 


\section{REFERÊNCIAS}

ALIANÇA DA TERRA; CCSX; IPAM; WHRC. Critérios, indicadores e meios de verificação para classificação das propriedades no Cadastro de Compromisso Socioambiental do Xingu. Fev. 2009. Disponível em: <http://www.ipam.org.br/biblioteca/livro/id/47>. Acesso em: 6 jan. 2013.

AMIGOS DA TERRA - AMAZÔNIA BRASILEIRA. Radiografia da carne no Brasil. São Paulo: Amigos da Terra - Amazônia Brasileira, 2013. Disponível em: <http://amazonia.org.br/wp-content/ uploads/2013/04/cartilha_radiografia.pdf > . Acesso em: 10 jan. 2013.

AMIGOS DA TERRA - AMAZÔNIA BRASILEIRA. A hora da conta: pecuária, Amazônia e conjuntura. São Paulo: Amigos da Terra - Amazônia Brasileira, 2009. Disponível em: < http:// commodityplatform.org/wp/wp-content/uploads/2009/05/a-horada-conta.pdf>. Acesso em: 12 jan. 2013.

AMIGOS DA TERRA - AMAZÔNIA BRASILEIRA. O reino do gado: uma nova fase na pecuarização da Amazônia brasileira. São Paulo: Amigos da Terra - Amazônia Brasileira, 2008. Disponível em: $<$ http://www.agropecuaria.org/agropecuaria/GanaderiaAmazonia. pdf>. Acesso em: 7 jan. 2013.

ASSOCIAÇÃO BRASILEIRA DAS INDÚSTRIAS DE ÓLEOS VEGETAIS (ABIOVE). Moratória da soja: $3^{\circ}$ ano do mapeamento e monitoramento do plantio de soja no bioma Amazônia. São Paulo, jul. 2010. Disponível em: <http://www.abiove.org.br/site/_FILES/ Portugues/07082012-160310-moratoria09_relatorio_jul10_b̌r.pdf $>$. Acesso em: 6 jan. 2013.

BARRETO, Paulo; SILVA, Daniel. Will cattle ranching continue to drive deforestation in the Brazilian Amazon? In: INTERNATIONAL CONFERENCE: ENVIRONMENT AND NATURAL RESOURCES MANAGEMENT IN DEVELOPING AND TRANSITION ECONOMIES, 1., Clermont Ferrand, 2010. Proceedings... Clermont Ferrand: CERDI - Centre of Studies and Research on International Development from the University of Auvergne, 2010. Disponível em: <http://cerdi.org/uploads/sfCmsContent/html/323/ Barreto.pdf $>$. Acesso em: 6 jan. 2013.

BARRETO, Paulo; SILVA, Daniel. Os desafios para uma pecuária mais sustentável na Amazônia. Estado da Amazônia, Belém, n. 14, p. 1-6, nov. 2009. Disponível em: <http://www.ibcperu.org/doc/ isis/11499.pdf>. Acesso em: 4 jan. 2013.

BARRETO, Paulo; PEREIRA, Ritaumaria; ARIMA, Eugênio. A pecuária e o desmatamento na Amazônia na era das mudanças climáticas. Belém: IMAZON, 2008.

BRANDÃO JR., A.; SOUZA JR., C. Deforestation in land reform settlements in the Amazon. State of the Amazon, Belém, n. 7, p. 1-4, jun. 2006.

BRASIL. Arco Verde. 2013. Disponível em: <http://www.mma. gov.br/legislacao/desenvolvimento-rural/category/31-arco-verde $>$. Acesso em: 12 jan. 2013.
BRITO, B.; BARRETO, P. A regularização fundiária avançou na Amazônia? Os dois anos do programa Terra Legal. Belém: IMAZON, 2011. Disponível em: <http://www.imazon.org.br/publicacoes/ livros/a-regularizacao-fundiaria-avancou-na-amazonia-os-dois-anosdo-programa-terra-legal-1>. Acesso em: 8 jan. 2013.

BUARQUE, Cristovam. A internacionalização do mundo. Jornal O Globo, Rio de Janeiro, 10 out. 2000. Disponível em: <http:// saojoaodelreitransparente.com.br/works/view/918>. Acesso em: 14 jan. 2013.

COHEN, M.; KONAR, S. Why do firms pollute (and reduce) toxic emissions. 2000. Social Science Research Network, mar. 2000. Disponível em: < http://ssm.com/abstract=922491>. Acesso em: jan. 2013.

FEARNSIDE, Philip M. Desmatamento na Amazônia: dinâmica, impactos e controle. Acta Amazonica, v. 36, n. 3, p. 395-400, 2006.

FOOD AND AGRICULTURE ORGANIZATION OF THE UNITED NATIONS (FAO). Livestock in the balance. In: FOOD AND AGRICULTURE ORGANIZATION OF THE UNITED NATIONS (FAO) (Org.). The state of food and agriculture. Roma: FAO, 2009. Parte I, p. 3-100.

FOOD AND AGRICULTURE ORGANIZATION OF THE UNITED NATIONS (FAO). Livestock long shadow, environmental issues and options: the livestock environmental development. Roma: FAO, 2006. (Annual Report). Disponível em: <http://www.fao. org/docrep/010/a0701e/a0701e00.HTM> . Acesso em: 8 jan. 2013.

FREEMAN, A. H.; THORNTON, P. K.; VAN DE STEEG, J. A.; MCLEOD, A. Future scenarios of livestock systems in developing countries. Animal production and animal science worldwide. WAAP Book of the Year 2006. Nairobi: International Livestock Research Institute; Roma: FAO, 2007. p. 219-232.

GOODLAND, Robert; ANHANG, Jeff. Livestock and climate change. What if the key actors in climate change are... cows, pigs, and chickens? World Watch, Washington, p. 10-19, nov.-dez. 2009. Disponível em: <http://www.worldwatch.org/files/pdf/Livestock\%20and\%20 Climate\%20Change.pdf > . Acesso em: 8 jan. 2013.

GREENPEACE. A farra do boi na Amazônia. 13 abr. 2010. Disponível em: <http://www.greenpeace.org/brasil/Global/brasil/ report/2009/6/FARRAweb-alterada.pdf> . Acesso em: 14 jan. 2013.

GREENPEACE. Amazon Cattle Footprint. Mato Grosso: state of destruction. 29 jan. 2009. Disponível em: < http://www.greenpeace. org/international/Global/international/planet-2/report/2009/1/ amazon-cattle-footprint-mato.pdf>. Acesso em: 20 jan. 2013.

INSTITUTO BRASILEIRO DE GEOGRAFIA E ESTATÍSTICA(IBGE). Censo 2010. Brasília: Ministério do Planejamento, Orçamento e Gestão, 2011a.

INSTITUTO BRASILEIRO DE GEOGRAFIA E ESTATÍSTICA (IBGE). Produção da pecuária municipal. Brasília: Ministério do Planejamento, Orçamento e Gestão, 2011b.

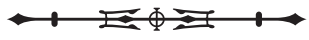


INSTITUTO BRASILEIRO DE GEOGRAFIA E ESTATÍSTICA(IBGE). Censo agropecuário 2006. Brasília: Ministério do Planejamento, Orçamento e Gestão, 2006.

INSTITUTO NACIONAL DE PESQUISAS ESPACIAIS (INPE). Programa de Cálculo do Desflorestamento da Amazônia (PRODES): desflorestamento nos municípios da Amazônia Legal. Ano base 2011. Disponível em: <http://www.dpi.inpe.br/prodesdigital/ prodesmunicipal.php> . Acesso em: 20 jan. 2013.

INSTITUTO NACIONAL DE PESQUISAS ESPACIAIS (INPE). Programa de Cálculo do Desflorestamento da Amazônia (PRODES): desflorestamento nos municípios da Amazônia Legal. Ano base 2009. Disponível em: <http://www.dpi.inpe.br/ prodesdigital/prodesmunicipal.php>. Acesso em: 20 jan. 2013.

KAIMOWITZ, David; MERTENS, Benoit; WUNDER, Sven; PACHECO, Pablo. Hamburguer connection fuels Amazon destruction. Jacarta, Indonésia: CIFOR, 2004. Disponível em: <http://www.cifor.org/ publications/pdf files/media/Amazon.pdf> . Acesso em: 4 jan. 2013.

KILLEN, Timothy J. A perfect storm in the Amazon wilderness: development and conservation in the context of the initiative for the Integration of the Regional Infrastructure of South America (IIRSA). Washington: Conservation International, 2007. (Advances in Applied Biodiversity Science, n. 7). Disponível em: < http://www. conservation.org/publications/Documents/AABS.7_Perfect_storm English.low.res.pd > . Acesso em: 14 jan. 2013.

LAPPÉ, Francis Moore. Diet for a small planet. Oakland: Small Planet Institute, 1971.

MEIRELLES FILHO, João. Por que criminalizar a pecuária na Amazônia? São Paulo, 18 maio 2009a. Disponível em: <http://www. vegetarianismo.com.br/sitio/index.php?option $=$ com_content\&task $=$ view\&id $=2429 \&$ Itemid $=33>$. Acesso em: 14 jan. $\overline{2013}$.

MEIRELLES FILHO, João. No faroeste mundial o Brasil é o meninoda-porteira. São Paulo, 8 dez. 2009b. Disponível em: <http:// www.vegetarianismo.com.br/sitio/index.php?option $=$ com conte nt\&task $=$ view\&id $=2503 \&$ Itemid $=103>$. Acesso em: 14 jan. 2013.

MEIRELLES FILHO, João. Amazônia: Carnaval ou Quaresma? São Paulo, 13 out. 2008. Disponível em: <http://www.vegetarianismo. com.br/sitio/index.php?option $=$ com_content\&task $=$ view\&id $=20$ 84\&Itemid=103 > . Acesso em: 14 jan. 2013.

MEIRELLES FILHO, João. Livro de ouro da Amazônia. 5. ed. Rio de Janeiro: Ediouro, 2007.

MEIRELLES FILHO, João; BARNEY, Maria Jose Gonzalez. Specialty of the day: delicious 500 gms of Amazonian beef steak produced by 7.000 grams of carbon dioxins, 7.000 litres of water, mixed with belched methane, is the ideal recipe for climate change. The Netherlands: Nature Inc. Questioning the Market Panacea in Environmental Policy and Conservation, jul. 2011. Disponível em: <http://www. iss.nl/fileadmin/ASSETS/iss/Documents/Conference_presentations/ NatureInc_Meirelles_and_Gonzalez.pdf>. Acesso em: 20 jan. 2013.
MINISTÉRIO DAAGRICULTURA, PECUÁRIAEABASTECIMENTO (MAPA). Assessoria de Gestão Estratégica. Brasil: projeções do agronegócio 2011/2012 a 2021/2022. Brasília, abr. 2012. Disponível em: <http://www.agricultura.gov.br/arq editor/file/Ministerio/ gestao/projecao/Projecoes\%20do\%20Agronegocio\%20Brasil\%20 2011-20012\%20a\%202021-2022\%20(2)(1).pdf>. Acesso em: 6 jan. 2013

MINISTERIO PÚBLICO FEDERAL (MPF). Procuradoria da República no Pará. MPF aponta o INCRA como o maior desmatador da Amazônia. Notícias, 6 jul. 2012. Disponível em: <http://www. prpa.mpf.gov.br/news/2012/mpf-aponta-o-incra-como-o-maiordesmatador-da-amazonia >. Acesso em: 13 jan. 2013.

MYERS, N. The primary source: tropical forests and our future. Nova York/Londres: WW Norton \& Co., 1986.

O ÍNDIO SEM TUTELA. Entrevista com Daniel Munduruku, concedida ao jornalista Fábio Rayel. Revista Raiz, s. d. Disponível em <http://revistaraiz.uol.com.br/portal/index.php?option=com content\&task $=$ view\&id =850\&ltemid $=184>$. Acesso em: 4 jan. 2013.

OSAVA, Mario. Cattle, the ignored predator. Rio de Janeiro: IPS, 2009.

REDE AMAZÔNICA DE INFORMAÇÃO SOCIOAMBIENTAL GEORREFERENCIADA (RAISG). Amazônia sob pressão. São Paulo: ISA, 2012.

REDE DE AGRICULTURA SUSTENTÁVEL (RAS). Norma para sistemas sustentáveis de produção pecuária. Jul. 2010. Disponível em: <http://www.imaflora.org/downloads/biblioteca/normaRAS pecuaria_2011.pdf > . Acesso em: 9 jan. 2013.

RIVERO, Sérgio; ALMEIDA, Oriana; AVILA, Saulo; OLIVEIRA, Wesley. Pecuária e desmatamento: uma análise das principais causas diretas do desmatamento na Amazônia. Nova Economia, v. 19, n. 1, p. 41-66, 2009. Disponível em: <http://www.scielo.br/scielo. php?pid $=$ S0103 $-63512009000100003 \&$ script $=$ sci_arttext $>$. Acesso em: 10 jan. 2013.

ROUNDTABLE SUSTAINABLE PALM OIL (RSPO). Princípios e critérios para produção sustentável de óleo de palma. Mar. 2006. Disponível em: <http://www.rspo.org/file/RSPO\%20Criteria\%20 Final\%20Guidance \%20with\%20NI\%20Document\%20 \%28Portuguese\%29.pdf > . Acesso em: 11 jan. 2013.

SALOMÃO, R. P.; VIEIRA, I. C. G.; BRIENZA JÚNIOR, S.; AMARAL, D. D.; SANTANA, A. C. Sistema Capoeira Classe: uma proposta de sistema de classificação de estágios sucessionais de florestas secundárias para o estado do Pará. Boletim do Museu Paraense Emílio Goeldi. Ciências Naturais, Belém, v. 7, n. 3, p. 297-317, 2012.

SCHUBART, Herbert O. R. Critérios ecológicos para o desenvolvimento agrícola das terras firmes da Amazônia. Acta Amazonica, Manaus, v. 7, n. 4, p. 559-567, 1977.

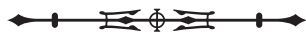


SIMPSON, S. S.; GARNER, J.; GIBBS, C. Why do corporations obey environmental law? Assessing punitive and cooperative strategies of corporate crime control. Washington, 2007. Disponível em: <https://www.ncjrs.gov/pdffiles1/nij/grants/220693.pdf>. Acesso em: 15 fev. 2013.

SPAROVEK, G.; BARRETO, A.; KLUG, I.; PAPP, L.; LINO, J. A revisão do Código Florestal Brasileiro. Novos Estudos, v. 88, p. 181-205, nov. 2010.
VALENTIM, J. F.; ANDRADE, Carlos M. S. Tendências e perspectivas da pecuária bovina na Amazônia brasileira. Amazônia: Ciência \& Desenvolvimento, Belém, v. 4, n. 8, p. 273-283, jan.-jun. 2009.

VERÍSSIMO, A.; ROLLA, A.; VEDOVETO, M.; FUTADA, S. M. Áreas protegidas na Amazônia brasileira: avanços e desafios. Belém: IMAZON; São Paulo: ISA, 2011. 
